\title{
Study of Intestinal Parasitosis among School Going Children in Pokhara, Nepal
}

\author{
${ }^{1}$ Kamal Singh Khadka, ${ }^{1}$ Hari Prasad Kaphle, ${ }^{2}$ Krishna Gurung, \\ ${ }^{3}$ Yogendra Shah, ${ }^{4}$ Manoj Sigdel \\ ${ }^{1}$ School of Health and Allied Sciences, Pokhara University, Lekhnath-12, Kaski, Nepal \\ ${ }^{2}$ Regional College of Science and Technology, Nayabazar-9, Kaski, Pokhara \\ ${ }^{3}$ Everest International Clinic and Research Center, Kalanki, Kathmandu, Nepal \\ ${ }^{4}$ Manipal Teaching Hospital, Pokhara, Nepal
}

\begin{abstract}
The study was carried out in order to estimate the prevalence of intestinal parasitosis in school-going children in schools located in Pokhara, Nepal from November 2011 to January 2012. A total number of 100 stool samples were collected from children of ages 3 to 15 years. A questionnaire including the factors predisposing to parasitosis was filled up and parasitic examination was carried out by direct wet mount examination and concentration method using standard formal ether concentration technique. The prevalence rate was found to be 15\%. Prevalence of parasitic infection was higher in girls (16\%) than in boys (14\%) and age group 8-12 years were found to be more suffering (17.3\%) than other age groups. The occurrence of parasitic infection in symptomatic children was found to be $40 \%$ and $10 \%$ in asymptomatic children. The symptoms were found statistically significant with infestation of parasites. Intestinal infection was highest in Dalit students (20\%) compared to other caste students. Prevalence of parasitic infection in other caste was $15 \%$ in Brahman, 9.5\% in Newar and 9\% in Chhetri. Among 15 positive cases 5 types of parasites were detected. The results showed Giardia lamblia to be the most common parasite. Occurrence of other intestinal parasites was Entamoeba histolytica (26.6\%), Ascaris lumbricoides (26.6\%), Trichuris trichura (6.6\%) and Hook worm (6.6\%). The study concluded that intestinal parasitosis is still public health problem among school going children of Pokhara valley especially among Dalit students.
\end{abstract}

Key words: Intestinal parasitosis, Formal ether concentration, Children, Pokhara, Nepal

Corresponding address: Kamal Singh Khadka, School of Health and Allied sciences, Pokhara University, Lekhnath-12, Kaski, Nepal. E-mail: khadka.sharada@yahoo.com

\section{INTRODUCTION}

Intestinal parasitic infections are most common in school going children and they tend to occur in high intensity in this age group. ${ }^{1,2,3}$ Higher prevalence of these infestations is closely correlated to poverty, poor environmental hygiene and impoverished health services. ${ }^{3}$ It is estimated that nearly 200 million people were infected with Giardia lamblia while Entamoeba histolytica infects $10 \%$ of the world population. ${ }^{4}$ In 1977 it was estimated that 45 million people carried Entamoeba histolytica in their intestine; $1 / 10^{\text {th }}$ of them suffer from intestinal invasion as a result 70 thousand people die each year. ${ }^{5}$ Intestinal parasitosis is one of the major public health and socio economic problem in Nepal. A hospital based study have shown a declining trend during a period of ten years. ${ }^{6}$ Poverty, lack of awareness, failure to practice proper hand washing after defecation, unsafe drinking water and use of improper toilets are some of the reasons that are not totally eradicated from most of the parts of our country. ${ }^{3,7}$ Because of these reasons most of the school going children are still suffering from parasitic infections. Socio-economic and cultural factors and lack of adequate basic sanitation have caused the children of Nepal vulnerable to intestinal parasitic infections. ${ }^{7}$ An intestinal worm has been one of the major causes of visiting health care facilities in the country.
It was the number one cause of morbidity for the healthcare visit in the year 2008/2009. ${ }^{8}$

Hence the present study was carried out to find the present situation of the parasitic infections among school going children in Nadipur area of Pokhara Valley.

\section{MATERIALS AND METHODS}

This cross-sectional study was carried out from November 2011 to January 2012. A total number of 100 stool samples were collected from school going children of Pokhara Valley in appropriate container. Samples were processed in the laboratory of Novel Academy, New road, Pokhara. A questionnaire on age, sex, hygienic practices and gastrointestinal symptoms were filled and used for analysis. Each fresh stool was examined with naked eye and under microscope. Laboratory analyses of faecal samples were carried out by formal ether sedimentation technique. ${ }^{9}$

\section{RESULTS}

The prevalence of parasitic infection was $15 \%(15 / 100)$ in which 14\% (7/50) were boys and 16\% (8/50) were girls. Prevalence of parasitic infection was higher in girls than in boys but the difference was statistically insignificant. 
Khadka et. al. Study of Intestinal Parasitosis among School Going ..... JHAS, 2013, Vol. 3, No. 1 P 47-50

Table 1: Gender wise distribution of intestinal parasites among school children

\begin{tabular}{|l|c|c|c|c|}
\hline Gender & $\begin{array}{c}\text { No. of } \\
\text { Children }\end{array}$ & $\begin{array}{c}\text { Positive } \\
\text { Cases }\end{array}$ & Percent & p-value \\
\hline Male & 50 & 7 & 14 & \multirow{2}{*}{$\mathrm{p}=0.77$} \\
\cline { 1 - 4 } Female & 50 & 8 & 16 & \\
\hline Total & 100 & 15 & 15 & \\
\hline
\end{tabular}

The occurrence of parasitic infection was highest in age group 8-12 years and lowest in age group12-15 years; however, it was statistically insignificant.

Table 2: Age wise distribution of intestinal parasites among school children

\begin{tabular}{|c|c|c|c|c|}
\hline Age group & $\begin{array}{c}\text { No. of } \\
\text { Children }\end{array}$ & $\begin{array}{l}\text { Parasite } \\
\text { positive }\end{array}$ & Percent & $\mathrm{p}$-value \\
\hline $3-5$ years & 25 & 4 & 16.0 & \multirow{4}{*}{$\mathrm{p}=0.934$} \\
\hline $5-8$ years & 41 & 6 & 14.6 & \\
\hline $8-12$ years & 23 & 4 & 17.3 & \\
\hline $12-15$ years & 11 & 1 & 9.0 & \\
\hline
\end{tabular}

The occurrence of parasitic infection in symptomatic (nausea, abdominal discomfort, diarrhea, cough, anaemia and foul stool) children was found to be $40 \%$ and in asymptomatic children $10 \%$. The symptoms were found statistically significant with infestation of parasites.

Table 3: Symptoms wise distribution of intestinal parasites among school children

\begin{tabular}{|l|c|c|c|c|}
\hline \multicolumn{1}{|c|}{ Symptoms } & $\begin{array}{c}\text { No. of } \\
\text { Children }\end{array}$ & $\begin{array}{c}\text { Positive } \\
\text { cases }\end{array}$ & Percent & p-value \\
\cline { 1 - 4 } Symptomatic & 15 & 6 & 40.0 & \multirow{2}{*}{$\mathrm{p}=0.003$} \\
\cline { 1 - 4 } Asymptomatic & 85 & 9 & 10.0 & \\
\hline Total & 100 & 15 & 15.0 & \\
\hline
\end{tabular}

Among 15 positive cases 5 types of parasites were detected. The most common intestinal parasite was Giardia lamblia which was reported as $33.3 \%$ (5/15 cases). Occurrence of other intestinal parasites was $26.6 \%$ Entamoeba histolytica (4/15 cases), 26.6\% Ascaris lumbricoides (4/15 cases), 6.6\% Trichuris trichura (1/15 cases) and 6.6\% Hook worm (1/15 cases) respectively.

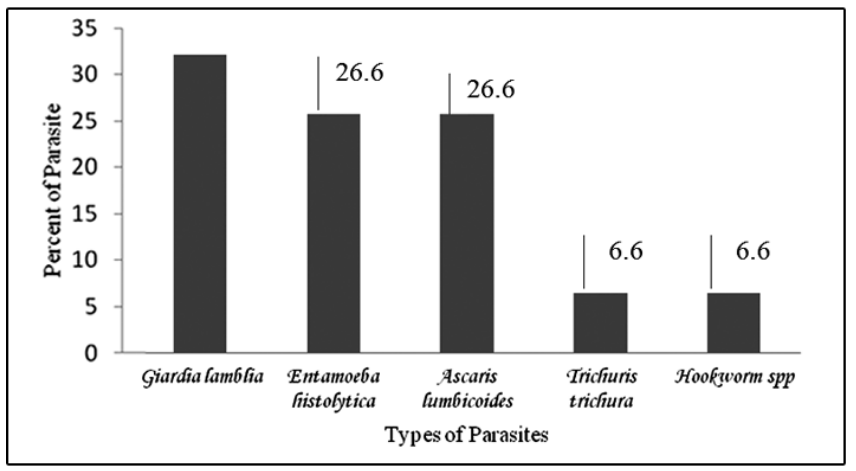

Figure 1: Frequency and category of parasites detected Intestinal infection was highest in Dalit students.
Table 4: Caste wise distribution of intestinal parasites

\begin{tabular}{|l|c|c|c|}
\hline \multicolumn{1}{|c|}{ Caste } & $\begin{array}{c}\text { No. of } \\
\text { children }\end{array}$ & $\begin{array}{c}\text { Frequency of } \\
\text { positive cases }\end{array}$ & Percent \\
\hline Brahman & 13 & 2 & 15.0 \\
\hline Chhetri & 11 & 1 & 9.0 \\
\hline Gurung & 5 & 0 & 0.0 \\
\hline Newar & 21 & 2 & 9.5 \\
\hline Dalit & 50 & 10 & 20.0 \\
\hline Total & 100 & 15 & 15.0 \\
\hline
\end{tabular}

\section{DISCUSSION}

The prevalence of parasitic infection was $15 \%$ in this study which was similar to the study done by Kunwor in which the prevalence of parasites in school going children of Pokhara was $17.3 \% .{ }^{10}$ In the study done by Chandrashekhar et. al., the prevalence of intestinal parasites in school going children of Kaski district was found to be $21.3 \%{ }^{11}$ A study conducted in two rural villages in Chitwan, Nepal in 1999 showed a $44 \%$ prevalence of intestinal parasites in schoolgoing children. ${ }^{12}$ The prevalence of parasitic infection in a study done by Sherchand et. al., in 2010 in school going children of Kathmandu valley was $51.9 \% .{ }^{6}$ Similarly the prevalence of parasitic infection in was reported to be $65.0 \%$ by Sherchand et. al., in and Rai et al. ${ }^{13,14}$ The result obtained in this study was not in agreement with the result obtained by Uga et. al., Meharaj et. al., and various other scientist of the world who performed their research in place other than western part of Nepal. ${ }^{15,16}$ But the prevalence of the study is in close agreement with result obtained in similar study that was conducted in school going children of Pokhara Valley. This concludes that the differences in geographical setting, socioeconomic conditions, cultural practices, awareness programmes and the supply of drinking water can bring vast differences in the prevalence of parasitic infections in different parts of the world. The result also showed that prevalence of parasitic infection in school going children of Kathmandu was more than that of Pokhara. This may be due to poor water supply system, highly polluted environment and overpopulation of Kathmandu Valley.

In this study the prevalence of parasitic infection was higher in girls than in boys. The finding of the present study was in agreement with the finding of Sherchand et. al., Kunwor Rup, Sherchand et. al., and Rai et. al., Sharma et. al., Rajeshwory et. al., Klinghtliner et. al., But in the study done by Rajeshwory et. al., and Klinghtler et. al., parasitic infection was gender dependent. ${ }^{6,10,13,14,17,19}$ More prevalence of parasitic infection in female in this area may be due to uneducated lower cast parents who give more priorities to the health of their sons than their daughters. Furthermore the children in Kopildhunga of poor Dalit parents are not aware of using well managed latrine and higher amount of sample were taken from Kopildhunga area. 
The occurrence of parasitic infection was highest in age group 8-12 years and lowest in age group12-15 years. This finding was in agreement with the study done by Sherchand et al. ${ }^{6}$ The prevalence of parasitic infection was found higher in age group less than 10 years in the study done by Poudyal et al.$^{20}$ This may be due to the carelessness of the children towards their personal hygiene and engagement of this age group child in different types of games in polluted environment.

The occurrence of parasitic infection in symptomatic children was found to be $40 \%$ and $10 \%$ in asymptomatic children. The symptoms were found statistically significant with infestation of parasites. This finding was in agreement with the study done by Sherchand et. al., Sherchand et. al., Adhikari et. $a l .^{6,13,21}$ Intestinal infection was highest in Dalit students in this study. Similar result was obtained in study done from a remote hilly village of western Nepal in 2001 that showed a prevalence of $71.4 \%$ in the lower economic class people. Dalits comprised the majority. ${ }^{21}$ This can be attributed to their inaccessibility to safe drinking water, unhygienic personal habits due to lack of knowledge and awareness and also indirectly to their occupation as farmers.

Altogether 5 different types of intestinal parasites were detected in the stool samples. The most common intestinal parasite was found to be Giardia lamblia. Occurrence of other intestinal parasites was Entamoeba histolytica (26.6\%), Ascaris lumbricoides (26.6\%), Trichuris trichura (6.6\%) and Hook worm (6.6\%). In a study done by Chandrashekhar et al Giardia lamblia (13.2\%), Ascaris lumbricoides (2.1\%) and
Entamoeba histolytica (1.7\%) were the commonest parasites isolated. ${ }^{11}$ Similarly among these parasites incidence of Giardia was higher in the study done by Sherchand et al. ${ }^{6}$ So our finding was found to be in agreement with the finding of other scientists who performed their research in western part of Nepal. But the prevalence of helminthes infection was higher than that of protozoan and Ascaris lumbricoides was the commonest intestinal parasite isolated in a study done by Kunwor. ${ }^{10}$ Sharma et. al., found the prevalence of helminthes infection was $76.9 \%$ and that of protozoa was $23.1 \%$. Shakya et al found the infection rate of helminthes about $56.5 \%$ and that of protozoa $43.5 \%{ }^{17,23}$ This differences in result may be due to the differences in environment of area selected for research, time of research and socioeconomic condition of parents and children that are selected for research purpose.

\section{CONCLUSION}

Prevalence of parasitic infection in school going children school is decreasing but it is still prevalent as major public health problems in school children. Giardia lamblia was found to be the major causative agent of intestinal parasitosis in Pokhara. Dalit cast parents and children should be provided awareness programme related with parasitic infection. In order to prevent this infection appropriate health education should be given to children and their parents concerning disease transmission, personal hygiene and safe drinking water. Efforts from the municipality to improve the quality of drinking water supply and the types of toilets being used will certainly curtail the number of parasitic infections in Pokhara.

\section{ACKNOWLEDGEMENT}

We express our gratitude to Surya Bahadur Khadka for his encouragement to conduct this study and Novel Academy for letting us to use the laboratory facilities needed in accomplishing this study. Similarly, we are thankful to the Principal and children of Little Bells Boarding School for their corporation during sample collection.

\section{REFERENCES}

1. Chandrashekhar TS, Joshi HS, Gurung M, Subba SH, Rana MS, Shivananda PG. Prevalence and distribution of intestinal parasitic infestations among school children in Kaski District, Western Nepal. Journal of Biomedical Science. 2005; 4:78-82.

2. Rai SK, Kubo T, Nakanishi M, Sumi K, Shibata H, Matsuoka A. Status of soil-transmitted helminthic infection in Nepal. Kansenshogaku Zasshi. 1994; 68:625-30.

3. Estevez EG, Levine JA, Warren J. Intestinal parasites in a remote village in Nepal. J Clin Microbiol. 1983; 17:160-1.

4. WHO. World Health Report 2000: Conquering Suffering Enriching Humanity. Geneva: WHO; 2000.

5. Das, R, Pradipta S, Kumar and Biswas R. Prevalence of intestinal parasites and its association with socio-demographic, environmental and behavioral factors in children in Pokhara, Nepal. Afr J Cln Exper Microbial. 2006; 7(2):106-15.

6. Sherchand PS, Joshi RD, Adhikari N, Gurung K, Pant K, Pun R et. al. Intestinal parasitosis among school going children. JHAS. 2010; 1(1):12-15.

7. Gyawali N, Amatya R, Nepal PH. Intestinal parasitosis in school going children of Dharan Municipality, Nepal. Trop Gastroenterol. 2009; 30(3):145-7.

8. Shrestha A, Narayan KC, Sharma R. Prevalence of Intestinal Parasitosis among School Children in Baglung District of Western Nepal. Kathmandu Univ. Med. J. 2012; 37(1):3-6.

9. WHO Regional Office for South East Asia. Guidelines on Standard Operating Procedure for Microbiology 2006. [Cited 2011 Aug 7]; Available from: http://www.searo.who.int/en/Section10/Section17/ Section53/Section482_1804.htm.

10. Kunwor R. Prevalence of intestinal parasitic infections among school going children in Pokhara, Nepal. Himilayan 
Scientific Journal. 2011; 4:23-25

11. Chandrashekhar TS, Joshi HS, Gurung M, Subba SH, Rana MS, Shivananda PG. Prevalence and distribution of intestinal parasitic infestations among school children in Kaski District, Western Nepal. Biomed Sciences. 2005; 4(1):78-82.

12. Yong TS, Sim S, Lee J, Ohrr H, Kim MH, Kim H. A small scale survey on status of intestinal parasite infection in rural village in Nepal. Korean J Parasitol. 2000; 38:275-7.

13. Sherchand JB, Ohara H, Sherchand S, Cross JH, Shrestha MP. Intestinal parasitic infections in rural areas of Southern Nepal. Inst Med J Nep.1997; 19:115-21

14. Rai SK, Hirai K, Abe A, Ohno Y. Infectious disease and malnutrition status in Nepal: An overview. Mal J Nutr. 2002; $8(2): 191-200$.

15. Uga S, Rai SK, Kimuru K, Ganesh R, Kiura D, Wakasugi M, Miyake Y, Ishiyama S, Rajbhandari TP. Parasites detected from diarrhoeal stool samples collected in Nepal. Southeast Asian Trop Med Public Health J. 2004; 35:19-23.

16. Mehraj V. Prevalence of and factors associated with intestinal parasites among children 1 to 5 years of age in an urban slum of Karachi [Ph D thesis]. Karachi, Pakistan: Department of Community Health Sciences, Age Khan University. 2006.

17. Sharma BK, Rai SK, Rai DR, Choudhry DR. Prevalence of intestinal parasitic infestation in school children in the northeastern part of Kathmandu Valley, Nepal. Southeast Asian J Trop Med Public health. 2004; 35(3):501-505.

18. Rajeshwori B, Siniah B, Hussein H. Socioeconomic factors associated with intestinal parasites among children in Gombank, Malaysia. Asian Pac J Public Health. 1994; 7(1):21-25.

19. Kightlinger LK, Seed JR, Kinghtlinger MB. Epidemiology of Ascaris Lumbricoides: Trichuris trichuria and hookworm in children in Ramonafana and rainforest, Madagascar. J Parasitol.1995; 81:159-169.

20. Poudyal AK, Jimba M, Silwal M, Silwal RC. Targeting newly enrolled low age school going children for control if intestinal helminthes infection in rural Nepal. Trop Doct. 2006; 36(1):16-9

21. Adhikari N, Rai SK, Singh A. Intestinal parasitic infection among HIV seropositive and high risk group subjects for HIV infection in Nepal. Nep Med Col J. 2006; 9:166-70.

22. Ishiyama S, Rai SK, Ono K, Uga S. Small-scale study on intestinal parasitosis in a remote hilly village in Nepal. Nepal Med Coll J. 2003; 5:28-30.

23. Shakya B, Rai SK, Rai G, Shrestha A, Singh A. Study on intestinal infections by parasite and some bacteria among elderly people of Kathmandu valley. Nepal Med Col J. 2006; 8(4):243-247. 